\title{
THE IMPACT OF WIND FARMS ON THE PRICES OF NEARBY HOUSES IN POLAND: A REVIEW AND SYNTHESIS
}

\author{
Marcin Torzewski, MA \\ Faculty of Management \\ University of Warsaw \\ e-mail:m.torzewski@hotmail.com
}

\begin{abstract}
Since 2009/10 Poland has experienced a dynamic growth of wind energy production. Currently, wind energy is the most popular resource of renewable energy in Poland. Despite the importance of wind energy for the Polish economy, there is no reliable and comprehensive research on the causal effects of wind farm facilities on property prices.

The aim of this article is to critically review existing research related to the impact of wind farms on prices of nearby residential properties. The article concentrates on Polish as well as international scientific literature. Besides presenting the main findings obtained from the review of literature, the article clusters these findings based on information that is crucial to the analysis: methodology, data, and subject of study. The literature review is followed by a description of the characteristics of wind energy in Poland, which includes differences in the location of wind farms between Poland and other countries. The article concludes that despite the fact that some international research points to a significant causal effect of wind farms on property prices, these results cannot be easily transposed to Polish circumstances. Based on the reviewed literature, the article moreover shows directions for improving future analyses in Poland, particularly with respect to the methodology.
\end{abstract}

Key words: wind farm, housing prices, causal effect.

JEL Classification: C18, Q29, R3.

Citation: Torzewski M., 2016, The Impact of Wind Farms on The Prices of Nearby Houses in Poland: a Review and Synthesis, Real Estate Management and Valuation, Vol. 24, No. 2, pp. 13-24.

DOI: 10.1515/remav-2016-0010

\section{Introduction}

Renewable energy (RE) is an alternative to conventional energy resources such as oil, gas and, specifically in the case of Poland, coal. The key advantages of RE are well-known and include, among others: the reduction of greenhouse gases and dust released into the atmosphere, and the inexhaustibility of energy supplies. Nowadays, Poland is forced to successively increase the share of $\mathrm{RE}$ in its total energy balance, particularly due to approved international agreements (e.g. Directive 2009/28/EC, 2020 Climate and Energy Package, Kyoto Protocol). Some changes in that respect are already taking place through investment incentives in the form of EU grants or subsidies for "green energy". Due to the energy potential of RE resources in Poland and the efficiency of energy production, priority has been given to biogas and wind energy. However, thanks to moderately good wind conditions, a system of subsidies and donations for wind energy, reliable technology used for constructing wind turbines and the smaller complexity of the project venture than in the case of biogas plants, wind energy is currently the most popular source of RE in Poland.

The dynamic development of wind turbines currently observed in Poland is followed by increasing public debate and research on the impact of RE (both at the macro- and micro-level). 
Opponents of wind energy argue that the construction of wind farms is associated with high social and economic costs, such as: 1) the deterioration of living conditions and a negative influence on health (noise, infrasounds and low frequency sounds, shadow flickering, vibrations), 2) spatial disorder and other vista effects, 3) a negative impact on birds and bats, and 4) a negative impact on property values located in the "wind farm influence zone". They postulate the introduction of special buffer zones, defined by the minimum distance of wind turbines from the nearest buildings. They also opt for financial compensation due to their negative impact on housing values. In contrast, supporters of wind farm development (including the strong lobby of RE developers and manufacturers) counter the opponents' arguments, pointing to the lack of conclusive evidence regarding the negative impacts of wind farms. Furthermore, they claim that wind farm facilities may even have positive effects on property values by increasing the attractiveness of the municipality, in which the RE plant is located (e.g. the creation of new jobs, a positive image of a pro-ecological municipality, etc.).

The aim of this research is to provide an in-depth analysis of the existing research on the economic consequences of RE infrastructure in Poland. The focus of the analysis is, however, placed mainly on wind farms and their effects on housing prices. Given the recent patterns in energy production in Poland and the evolving debate on the consequences of the development of RE sites, the present article structuralizes existing knowledge and discusses recent evidence regarding the analysis of the economic effects of wind farm facilities on housing prices. Despite the importance of these results to the economy, there is no reliable and comprehensive source of knowledge regarding the role of RE sites on the value of properties in Poland. The goal of the article is, thus, to complement and synthesize existing empirical evidence and suggest the most appropriate methodology for future research to provide accurate and reliable results.

The research is conducted based on a review and discussion of the main findings obtained from existing literature on the topic. The description of the results is then synthesized in a table that groups them according to information which is essential to the final outcome, i.e.: methodology, data, subject of the study. By doing so, the article provides comprehensive data on the existing research, enabling comparative analysis. The review of literature is furthermore complemented with a description of wind energy production in Poland. While focusing on Poland, the research indicates differences between wind farms located in Poland and in the compared countries (where most of the quantitative analyses have been so far carried out). The results show that, in Poland, current research regarding the impact of wind farms focuses mainly on cost-benefit analysis (e.g. LIGUS 2009) or qualitative analysis (e.g. HRYNKIEWICZ 2014). Quantitative and reliable analyses are, however, scarce. On the other hand, in international scientific literature, there is a growing interest in statistical and casual analysis of the impact of wind farms on housing prices. The obtained results show either no statistical significance (e.g. SIMS et al. 2008; CARTER 2011; HOEN 2013), or a statistically significant negative causal effect (e.g. HeintZelman, TutTle 2011; SunAK, MADlENER 2013; DRÖES, KOSTER 2014). The article concludes that there is a need to conduct reliable quantitative analysis that uses appropriate methods to assess the economic consequences of wind farms in Poland. Finally, the article suggests and briefly describes the research methods that are now most commonly used in international research regarding the topic and could also be applied in the case of Poland.

The paper is structured as follows. First, the current situation of wind energy in Poland is characterized and summarized in SWOT analysis. The next section presents the topic in a comparative - international level - framework. The third section focuses on reviewing the most crucial research on the topic. The fourth section presents the main quantitative methods used for the evaluation of the effects of the external factors on housing prices. Finally, section five concludes the work and presents the directions for future research regarding the evaluation of the impact wind farms have on housing prices.

\section{Wind energy sector in Poland}

Poland is a country in transition with respect to the production of energy. Currently, the country is experiencing a change from coal monoculture to the diversification of energy resources. Prior to 1989, the Polish economy was mostly based on heavy industry, which needed cheap, easily available and reliable sources of energy. To a large extent this was possible thanks to the massive resources of coal. In 1989, Poland was producing app. 175.9 mega tons of steam coal, being one of the top coal producers in the world (Energy Resources in Poland). However, along with the structural transition from heavy industry to a service-based economy, the need for coal production has been gradually decreasing. 
Other factors that contributed towards the change in this status quo included: the need to diversify energy resources (due to reasons connected with energy security and political pressure), increasing costs of coal-mining, obsolete technology, environmental protection, and pressure for so-called sustainable development. As a result, in 2013, Poland produced 65.97 mega tons of steam coal $\left(10^{\text {th }}\right.$ place in the world), which constitutes a drop of over 60\% as compared to 1989 (Energy Resources in Poland). Despite this dramatic decline in coal production, coal is still the top source of energy in Poland. This situation is specifically affecting the generation of electricity, because heat production is, to a certain degree, supported by the import of gas. In 2013, 84\% of electricity in Poland was generated from coal (both steam and brown coal), (Energy Statistics in 2012 and 2013). Polish dependence on coal as the prime source of energy is, however, dangerous for political, environmental and economic reasons.

Since the accession of Poland to the EU there has been political pressure - both at the national and international level - to increase the share in energy production from other sources of energy, in particular from RE. Poland is also officially obliged by the EU law (e.g. Renewable Energy Directive 2009/28/EC) to increase the share of RE in total gross energy consumption to $15 \%$ by 2020 (from $7.2 \%$ in 2005). Detailed goals related to RE in Poland, together with actions plans, are described in documents of strategic and legal importance at the state level (e.g. Energy Policy of Poland until 2030, National Renewable Energy Action Plan).

Among the existing renewable resources, the most popular alternative to conventional sources of energy in Poland is wind energy. A brief summary of the present situation regarding this source of RE in Poland has been presented in the form of a SWOT ${ }^{1}$ matrix in Table 1. In 2014, nearly $50 \%$ of all electricity produced from RE was generated from this source (Global Wind Report ...2014). The Polish market for wind farms is, however, still developing, and since 2009/10, Poland has experienced a dynamic growth, both in terms of annual consumption and installed power generation capacity of wind energy. Between the years 2013 and 2014, total consumption increased by almost 28\%, and the total installed power generation capacity by 13\% (see Fig. 1 and Fig. 2).

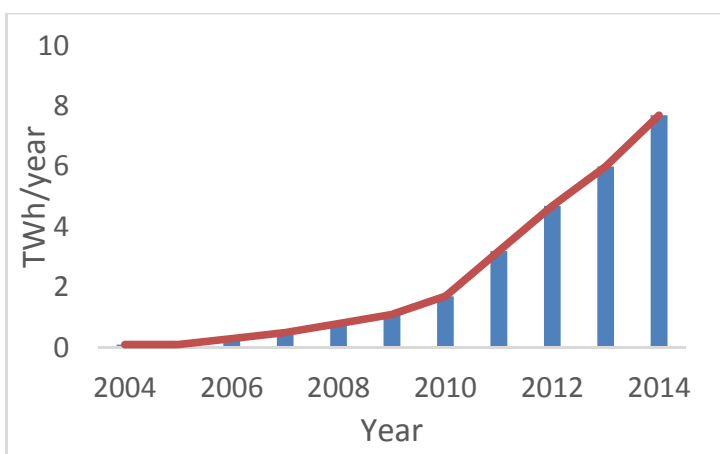

Fig. 1. Annual consumption of wind energy in Poland (TWh/year). Source: own work based on Global Wind Report...2014.

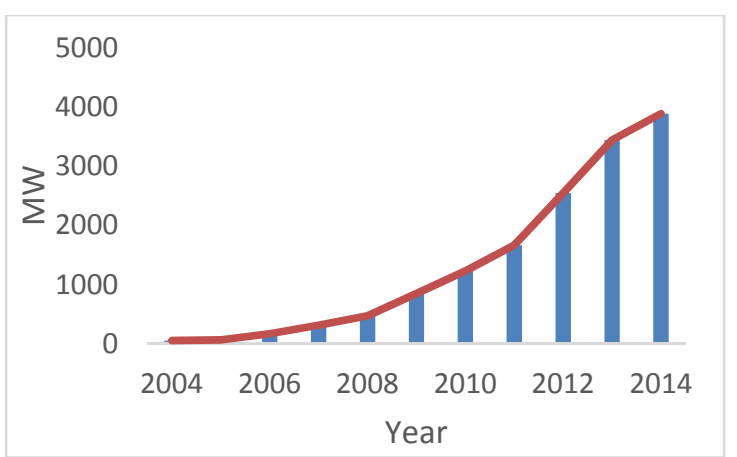

Fig. 2. Cumulative installed power generation capacity of wind energy in Poland (MW). Source: own work based on Global Wind Report...2014.

Table 1

SWOT analysis for wind farm market in Poland

\begin{tabular}{lc}
\hline \multicolumn{1}{c}{ Strengths } & Opportunities \\
\hline - Inexhaustible and renewable source of energy & - EU and international pressure to increase the \\
- The most popular RE source in Poland (app. & country's level of RE balance \\
$50 \%$ share in the total RE electricity balance) & - Policy pressure at the state level to develop RE \\
- Reduction of the greenhouse effect & - Donations and system of subsidies for \\
- Local taxes for the commune & electricity that is produced from wind turbines \\
- A positive (pro-ecological) image communities & (e.g. donations for the development of \\
\hline
\end{tabular}

${ }^{1}$ SWOT analysis is a framework commonly used to evaluate the strengths $(\mathrm{S})$, weaknesses $(\mathrm{W})$, opportunities $(\mathrm{O})$ and threats $(\mathrm{T})$ of an organization. 
where wind farms are located

- New wind turbines based on high technology that helps to optimize the production of RE

- The lack of odour emission (contrary to biogas plants)

Weaknesses
- Stigmas: area, nuisance, scenic vista, (HoEN et
al. 2009), wind farm anticipation stigma
(HINMAN 2010)
- Location that depends on wind conditions
- Limited effectiveness (many turbines produce
less than 30\% of their production capacity)
- High costs - production of energy is more
expensive than in the case of conventional
sources
- Expensive technology (mainly imported from
Western European countries)
- Competitiveness that depends on the system
of incentives and donations

infrastructure, green certifications, obligation for electricity providers to purchase energy produced from renewable sources)

Source: own work.

\section{Wind farm location - a national perspective}

Although there are differences between Poland and other EU countries with respect to the legal and administrative procedures that take place from the moment the decision to build a plant is made to the actual start-up of the plant - they are not important to this study. As the analysis of other EU countries shows, the procedure is similar and, in general, comes down to the need to obtain building permission as well as permission to connect a wind turbine to the power grid, and undergoing environmental impact assessment. More specific legal requirements that are needed for building wind farms will, thus, not be elaborated on in this section. Instead, the section will reveal and discuss the main discrepancies that may be observed between the countries and relating to regulations concerning the location of wind farms in developed residential areas.

In Poland, there is a lack of legal norms regarding the minimal distance (the distance setback) of a wind turbine from the nearest residential area. There are, however, regulations that refer to the level of noise emitted, which depends on the time of day. For instance, for one-family residential houses the noise limit is equal to $50 \mathrm{~dB}$ during the day and $40 \mathrm{~dB}$ at night, whereas for multi-family residential houses - $55 \mathrm{~dB}$ in the day and $45 \mathrm{~dB}$ at night (Regulation of the Minister of the Environment...2012). The level of noise is measured when the speed of the wind is below $5 \mathrm{~m} / \mathrm{s}$, which does not reflect the real intensity of noise generated by wind turbines working at their effective level, which is estimated at approximately $10-12 \mathrm{~m} / \mathrm{s}$. Therefore, according to the Supreme Audit Office in Poland, the methodology of measuring noise emission does not guarantee a reliable assessment of wind farm location (Location and Construction of Wind Farms...). Furthermore, the development of a new technology that is used in wind turbines contributes to lower levels of noise. As a consequence, noise regulations results in wind turbines being located in close proximity of residential houses.

In other countries, different approaches to regulating the location of wind farms in developed residential areas exist. For example, in Denmark, distance setbacks are defined by the noise regulations (for the open countryside: $42-44 \mathrm{~dB}$; for noise-sensitive land use: $37-39 \mathrm{~dB}$; depending on the wind speed), and distance regulations (minimum distance from nearby houses is 4 times the total height of a turbine). On the other hand, in the Netherlands - similarly to Poland - there are noise emission limits (a daytime limit of $47 \mathrm{~dB}$ and night limit of $41 \mathrm{~dB}$ calculated based on the average annual noise emission) (NIEUWENHUIZEN, KÖHL 2015). However, recently the Netherlands also passed a law establishing a list of new wind farm locations (in chosen regions) (DRÖES, KOSTER 2014). In Germany, at the federal level, there is a law defining the minimum distance by noise regulations (in the country, villages and mixed areas: $45 \mathrm{~dB}$; mostly residential and small urban areas: $40 \mathrm{~dB}$; purely urban areas: $35 \mathrm{~dB}$; noise limits calculated cumulatively, i.e. with other sources of noise). At the state (land) level, German lands may implement additional limitations (i.e. distance setbacks) for wind farm 
locations (NIEUWENHUIZEN, KÖHL 2015). In the USA, regulations vary between the states, despite the fact that the New York State Energy Research and Development Authority recommends that the wind turbines should be located at least app. $300 \mathrm{~m}$ away from residential areas (HEINTZELMAN, TUTTLE 2011). Finally, in England, there are no minimum national distances or noise setbacks for wind turbines (SMITH 2015).

Poland and other countries differ not only in terms of legal aspects concerning the location of wind farms, but also in their socio-economic background related to the production of wind energy. Contrarily to Poland, all of the above-mentioned countries have been developing wind energy production for decades. As a result, the production of wind energy in these countries constitutes a high share of total energy production. People living in these countries are already accustomed to the land image shaped by wind turbines. Moreover, wind farm investors take into account the interest of stakeholders and, despite the fact that in England and in Wales there are no distance or noise setbacks for wind turbines, wind power plants are rarely located close to residential houses. In the USA, due to the huge acreage of land, wind farms are mostly dispersed and their vista effects differ substantially when compared to the Netherlands or Denmark. Given these differences, existing research focusing on various countries should be considered with caution, as it encompasses the endogenous characteristics of the region for which it is performed, and thus, cannot be easily transposed to Polish circumstances.

\section{Existing national and international research: Literature review}

Polish scientific literature related to the valuation of the effects of wind farms on property prices is rather limited. In general, existing literature may be divided into two main research streams. The first stream of research (e.g. HRYNKIEWICZ 2014) focuses on qualitative analysis and is mostly limited to characterizing the advantages and disadvantages of wind farm locations in Poland. The second stream of research (e.g. LIGUS 2009), in turn focuses on the cost-benefit analysis of wind farm installation. However, both research domains neglect the quantitative effects of wind farm installation on nearby properties. Only recently, have some attempts to identify these effects been undertaken. In particular, KOMORNICKI et al. (2011) present a study that constitutes a part of an expertise ordered by the Marshal's Office of the Pomeranian Province from the Polish Academy of Sciences. In their research, they first study the changes in offer prices for properties located near a wind farm situated in Dobrzyń (Pomeranian Province). Next, the analysis is extended to include 3 other wind farm facilities situated in Karlino, Dobrzyń and Kisielice. The analysis in this case is based on transaction prices obtained from the Agricultural Property Agency. In both cases, they limit the scope of the analysis to the distance from the wind farm. The research focuses on the effects on properties located within 8 $\mathrm{km}$ of a wind farm. Quantitative analysis in both parts of the research is limited to the examination of basic descriptive statistics (mean offer and transaction price, and volume of sales). The reliability of these quantitative findings is, thus, questionable.

On contrary, existing international scientific literature on the effects of RE and, in particular, wind farm locations on the prices of nearby properties is considerably well developed. Within the last decade, there has been increasing interest in scientific literature in identifying the causal effect of wind farms on housing prices in Western European countries as well as in the USA. As a result, current research on the topic is very often based on the econometric analysis of large data sources, using advanced methods that aim to provide an unbiased, i.e. causal, estimate of the required effect. International research focuses mostly on countries which have a substantial share of RE sources in total energy production - mainly: Germany, the Netherlands, the USA, the UK and Denmark. Among the most important recent studies, it is worth mentioning: SIMS et al. (2008); HINMAN (2010); CARTER (2011), HeintZelman, TutTLE (2011); SunAK, MADLENER (2013); HoEN et al. (2009), (2013); LANG et al. (2014); GIBBONS (2014); DRÖES, KOSTER (2014). Below, the most important findings from their studies are briefly summarized and presented in a synthetic table at the end of the section. The aim of this review is to show the evolution of methodological approaches, from simple hedonic pricing models using regression analysis, to more advanced methods, such as spatial fixed effects or difference-indifference models.

One of the first studies that uses the regression model is that of SIMS et al. (2008), whose aim is to quantify the impact of wind farms on housing prices in the UK. The time span of the research is limited to the period of 2000-2007. The analysis is, moreover, limited by the distance of the wind farm 
to nearby houses, which is set at app. $0.8 \mathrm{~km}$, and neglects observations beyond this distance. The resulting sample used for estimating the impact is relatively small and consists of 201 individual observations from 16 wind turbines. SIMS et al. (2008) aim to estimate the effect of wind farm location controlling for other factors that could potentially affect housing prices. In particular, they account for such variables as: house characteristics, view, wind farm characteristics, and the year of the sales transactions. Controlling for the visibility of wind turbines, they provide some evidence that certain factors such as noise or flicker from the wind turbine might influence the price of the property. Overall, however, their results do not reveal a significant causal effect of wind farm location on property prices (SIMS et al. 2008).

On the other hand, HINMAN'S (2010) study examines the influence of wind farm proximity on housing prices in Illinois (USA) and changes in price depending on the stage of wind farm development. She shows that there is a change in the price of properties even before the actual building of the wind farm. In particular, she finds statistically significant evidence that "properties near the eventual wind farm site were valued less on average than properties located farther away from the eventual wind farm site" (HINMAN 2010), even though the wind farms had not yet been approved. She termed this finding "wind farm anticipation stigma". Her findings also reveal that as the development stage advances, the impact of the wind farm on housing prices diminishes. Hinman suggests that this might be due to the fact that the "unfamiliar' is becoming "familiar", and thus people becoming accustomed to the new circumstances shaped by wind turbines. The results show that following the actual construction of the wind farm, prices of nearby houses appreciated faster than those of houses located farther away (HINMAN 2010).

FOLLOWING Hinman (2010), Carter (2011) noticed that four separate stigmas related to wind farm development can be distinguished. Three of them were defined by HOEN et al. (2009), namely: area, nuisance and scenic vista stigmas, whereas the forth - wind farm anticipation stigma - by HINMAN (2010). The main characteristics of all four stigmas have been presented in Table 2.

Table 2

Characteristics of stigmas connected with wind farms

\begin{tabular}{|c|c|c|c|}
\hline Stigma & Author & Description & Impact \\
\hline Nuisance & $\begin{array}{l}\text { Hoen et } \\
\text { al. } 2009\end{array}$ & Turbine noise or shadow flicker & Nearby houses \\
\hline Area & $\begin{array}{l}\text { Hoen et } \\
\text { al. } 2009\end{array}$ & $\begin{array}{l}\text { Turbine presence affects surrounding area (becomes } \\
\text { more developed), regardless of the visibility criteria } \\
\text { from an individual house }\end{array}$ & $\begin{array}{l}\text { Nearby and more } \\
\text { remote houses }\end{array}$ \\
\hline Scenic vista & $\begin{array}{l}\text { Hoen et } \\
\text { al. } 2009\end{array}$ & Turbine visibility degrades a scenic vista & $\begin{array}{l}\text { Nearby and more } \\
\text { remote houses }\end{array}$ \\
\hline $\begin{array}{l}\text { Wind farm } \\
\text { anticipation }\end{array}$ & $\begin{array}{l}\text { Hinman } \\
2010\end{array}$ & $\begin{array}{l}\text { Uncertainty as to where and when turbines will be } \\
\text { located }\end{array}$ & $\begin{array}{l}\text { Nearby and more } \\
\text { remote houses }\end{array}$ \\
\hline
\end{tabular}

Source: own work based on CARTER (2011).

In his study, CARTER (2011) particularly focuses on the area stigma arguing that the "area stigma is the most important to test for because the different stigmas are not mutually exclusive. As area stigma is the most general of stigmas and easiest to test for, it makes sense to test for its presence first and investigate further if necessary". He investigates 1,298 observations from the period of 1998-2010 registered in Lee County, Illinois (USA). The findings do not reveal statistical evidence for the hypothesis that wind farms affect nearby houses. His results are consistent with HoEN et al. (2009, 2013), who also examined Lee County in a broader analysis that also covered other counties from various American states.

The study of HOEN et al. (2013) constitutes a comprehensive analysis of the impact of wind farms on housing prices in the USA, covering 9 states (27 counties) and over 51 thousand observations between 1996-2011. Despite the fact that HOEN et al. (2013) collected a substantial dataset, they were not able to find statistical evidence that the prices of houses located near wind farms were affected in any phase of the development of these complexes. This lack of an effect might be the result of a limited sample of data concerning houses located less than $1.6 \mathrm{~km}$ away from wind farms. HoEN et al. (2013), however, suggest that, based on up-to-date experience (e.g. studies of the impact of high-voltage 
transmission lines on property values), there are basis to expect a small negative impact of wind farms (less than $4 \%$ ). They conclude that data collected on houses located in the nearest proximity of wind farms is crucial for the analysis and understanding of these effects.

Contrary to CARTER (2011) and Hoen (2013), Heintzelman and TutTle (2011) find statistically significant evidence for the impact of wind farms on housing prices in the case of New York state in the USA. Their analysis relies on a sample size of 11, 369 sales transactions covering the period of 2000-2009. To investigate the causal effect, they use a regression model based on repeat-sales data. The repeat-sales method allows for analyzing only houses that were sold at least twice during analyzed time span. The dataset structure thus makes it possible to control fixed effects connected with the internal characteristics of a house. The results obtained from their research reveal a $10.87-17.77 \%$ decrease for properties located less than app. $0.8 \mathrm{~km}$ from a wind turbine, and around a $7.73-14.87 \%$ loss in the property values for a distance of app. $0.8-1.6 \mathrm{~km}$.

Another seminal work with respect to the identification of the effect of wind farms on property prices is the work of SUNAK and MADLENER (2013), who focus on the German market. Their analysis is carried out for the North Rhine-Westphalia region, covering the period of 1992-2010, and containing 1,405 observations. The analysis is based on a "hedonic pricing model, using both a spatial fixed (viewshed) effects (accounting for spatially clustered unobserved influences) and Geographically Weighted Regression (GWR) model (accounting for spatial heterogeneity)" (SUNAK, MADLENER 2013). They argue that controlling for visibility effects makes it possible to account for the importance of the view of wind turbines from the houses that might be hidden by merely the proximity factor. For instance, even though a house might be located in the immediate neighbourhood of a wind turbine, its effects might not be noticed since the house may be separated by a kind of infrastructure, trees or landform, which basically makes the turbine invisible. SUNAK and MADLENER (2013) control the visibility of wind farms using a GIS application, which allows for accurate derivation of views for each property in 3D. The results obtained from the GWR model reveal no statistical evidence for the impact of visibility. Results based on spatial fixed effects (4 various models) and the GWR model, however, show that wind farm proximity has a significant effect on housing value. Results obtained from the spatial fixed effects model reveal a negative effect of wind farms of around $21.5-29.7 \%$ for $0-1 \mathrm{~km}$. For further distances $(1-1.5 \mathrm{~km})$ the negative impact is lower $(15.3-17.5 \%)$ and less statistically significant (significance at the level of 10\%). The results obtained for distances of over $1.5 \mathrm{~km}$ from a wind farm show a negative and decreasing impact; they are, however, not statistically significant.

Recently, Lang et al. (2014) examined the impact of individual wind turbines on housing values in Rhode Island - the smallest state in the USA. Contrary to research conducted by HoEN et al. (2013), this study focuses on relatively densely populated areas. As a result, the dataset used for the analysis contains 48,554 observations in a fairly small study area. The database also includes 3,254 observations located less than $1.6 \mathrm{~km}$ from a turbine, of which 584 observations $(1.2 \%$ of the total sample) are located less than $0.8 \mathrm{~km}$ from a turbine. Furthermore, the wind turbines analyzed by LANG et al. (2014) were relatively small, ranging between 47-123 meters high with a nameplate capacity between 0.11.5 MW. Their analysis relies on the difference-in-difference model. The use of this model requires the researcher to possess data that relate both to the period before and after the building of the farm. According to the authors, the results reveal that "wind turbines have no statistically significant impacts on house prices, in either the post public announcement or post construction phase. The difference-in-difference models indicate that turbines are built in less desirable areas to begin with, which is consistent with intuition, because several turbines are built near highways or industrial areas" (LANG et al. 2014). They conclude that the analysis should be repeated to improve the accuracy and consistency of the results once newer data become available.

Similarly to LANG'S et al. (2014) analysis, GIBBONS (2014) also applied a hedonic regression model with the use of the difference-in-difference estimation method. His analysis focuses on wind farms located in England and Wales. The study covers nearly 38 thousand observations for the period between 2000-2011. The research strategy followed by the author is "to compare the average change in housing prices in areas where and when wind farms become operational and visible, with the average change in housing prices in some comparator group" (GIBBONS 2014). The results show a decrease in housing prices where wind turbines are visible. On average the estimated price reductions are around $5-6 \%$ for a $2 \mathrm{~km}$ visibility zone, less than $2 \%$ for visibility zones between $2-4 \mathrm{~km}$, and close to zero for visibility zones between $8-14 \mathrm{~km}$. Based on this, the author concludes that there is a direct link 
between the price change and the visibility of the wind turbines and "price reductions are directly attributable to turbine visibility"(GIBBONS 2014). The uncovered changes in housing values, however, also relate to physical aspects of visible wind turbines, such as the quantity, size and power capacity. For instance, wind farms having more than 20 turbines and located within a $2 \mathrm{~km}$ visibility zone reduce prices, on average, by nearly $12 \%$, whereas wind farms with fewer than 10 turbines affect house prices by only $5 \%$ (GIBBONS 2014).

Recently, DRÖES and KOSTER (2014) also followed the difference-in-difference estimation strategy and examined a huge dataset of housing transactions in the Netherlands covering the period 19852011 (app. 150 thousand observations). Contrary to American researchers, they focus on individual wind turbines in order to: "accurately measure the effect of distance (to the nearest turbine), the impact of wind turbine characteristics (e.g. height, diameter of blades, "shadow" areas, direct view), and the effect of multiple treatments (number of wind turbines)" (DRÖES, KOSTER, 2014). Their results suggest that after the construction of a wind turbine, house prices decrease, on average, by $1.4 \%$ to $2.3 \%$ if they are located within $2 \mathrm{~km}$ zones from a turbine. The analysis also reveals that the negative effects of turbine presence are already experienced 3 years prior to wind turbines becoming operational, which may be attributed to the anticipation stigma described by HINMAN (2010).

Finally, despite the recent evolution of quantitative research concerning the effects of wind farms on housing prices that are based on transaction data, survey-based analyses also exist (e.g. KHATRI 2004). One recent study of this kind was conducted by WALKER et al. (2014) who examined the perception of the impact of wind turbines on real estate values. This micro-level analysis carried out in Ontario, Canada, combines face-to-face interviews with a community survey from the neighbouring areas affected by the proximity of wind turbines. The findings are not consistent among the examined communities. WALKER et al. (2014) argues that, despite the evolution of quantitative research on the topic that provides hard data, the sociological approach should not be neglected as "homes that are very negatively affected by the development may not be part of the dataset at all" (WALKER et al. 2014). So far, due to the scarcity of data on housing transactions within the nearest proximity of wind turbines (i.e. $0.5 \mathrm{~km}$ ), econometric research fails to present statistically significant results that confirm their negative effects on housing values. This data limitation results in the inability to explain the real impact of wind turbines on the closest neighborhood and quantify the impact of turbine noise and visibility effects, which are mostly experienced in the immediate surroundings.

Table 3

Synthesis of existing empirical research on the causal effects of wind farms on property prices

\begin{tabular}{|c|c|c|c|c|c|c|}
\hline Author(s) & $\begin{array}{l}\text { Year of } \\
\text { survey }\end{array}$ & $\begin{array}{c}\text { Country of } \\
\text { survey }\end{array}$ & $\begin{array}{c}\text { Estimated } \\
\text { impact on prices }\end{array}$ & Methodology & Data & $\begin{array}{c}\text { Subject } \\
\text { of study }\end{array}$ \\
\hline SIMS et al. 2008 & $\begin{array}{l}2000- \\
2007\end{array}$ & UK (Cornwall) & No & $\begin{array}{l}\text { Multivariate linear } \\
\text { regression }\end{array}$ & 201 & $\begin{array}{l}16 \text { wind } \\
\text { turbines (each } \\
\text { app. } 60 \mathrm{~m} \\
\text { high) }\end{array}$ \\
\hline HINMAN 2010 & $\begin{array}{l}2001- \\
2009\end{array}$ & $\begin{array}{l}\text { USA (Illinois: } \\
\text { McLean } \\
\text { County) }\end{array}$ & $\begin{array}{l}\text { Negative for } \\
\text { anticipation } \\
\text { stigma }(-11.8 \% \text { for } \\
\text { ca. } 0-4.8 \mathrm{~km}) \text { and } \\
\text { none for area } \\
\text { stigma }\end{array}$ & $\begin{array}{l}\text { Regression based on } \\
\text { DID model }\end{array}$ & 3,851 & $\begin{array}{l}\text { Wind farms } \\
\text { (2facilities) }\end{array}$ \\
\hline $\begin{array}{l}\text { HEINTZELMAN, } \\
\text { TUTTLE } 2011\end{array}$ & $\begin{array}{l}2000- \\
2009\end{array}$ & USA (NY) & $\begin{array}{l}\text { Negative: } \\
-10.9 \% \text { to }-17.8 \% \\
\text { for } 0-0.8 \mathrm{~km}\end{array}$ & $\begin{array}{l}\text { Repeat-sales } \\
\text { regression } \\
\text { framework }\end{array}$ & 11,369 & $\begin{array}{l}\text { Wind farms (5 } \\
\text { facilities) }\end{array}$ \\
\hline CARTER 2011 & $\begin{array}{l}1998- \\
2010\end{array}$ & $\begin{array}{l}\text { USA (Illinois, } \\
\text { Lee County) }\end{array}$ & No & $\begin{array}{l}\text { Multivariate linear } \\
\text { regression }\end{array}$ & 1,298 & $\begin{array}{l}\text { Wind farms (3 } \\
\text { facilities) }\end{array}$ \\
\hline $\begin{array}{l}\text { HOEN et al. } \\
2013\end{array}$ & $\begin{array}{l}1996- \\
2011\end{array}$ & $\begin{array}{l}\text { USA (9 states: } \\
\text { IA, IL, MN, NJ, } \\
\text { OH, OK, PA, } \\
\text { WA, NY) }\end{array}$ & No & $\begin{array}{l}\text { Regression based } \\
\text { DID model } \\
\text { (proximity of wind } \\
\text { turbines) }\end{array}$ & 51,276 & $\begin{array}{l}\text { Wind farms } \\
\text { (67 facilities) }\end{array}$ \\
\hline $\begin{array}{l}\text { SUNAK, } \\
\text { MADLENER } \\
2013\end{array}$ & $\begin{array}{l}1992- \\
2010\end{array}$ & $\begin{array}{l}\text { Germany } \\
\text { (Rheine, } \\
\text { Neuenkirchen) }\end{array}$ & $\begin{array}{l}\text { Negative: } \\
-21.5 \% \text { to }-29.7 \% \\
\text { for } 0-1 \mathrm{~km}\end{array}$ & $\begin{array}{l}\text { Hedonic pricing } \\
\text { model, using both a } \\
\text { spatial fixed effects }\end{array}$ & 1,405 & $\begin{array}{l}\text { Wind farm (9 } \\
\text { turbines, each } \\
1,5 \mathrm{MW} \text { and }\end{array}$ \\
\hline
\end{tabular}




\begin{tabular}{|c|c|c|c|c|c|c|}
\hline & & & & $\begin{array}{l}\text { (viewshed) effect } \\
\text { and GWR model }\end{array}$ & & 100 m high) \\
\hline $\begin{array}{l}\text { LANG et al. } \\
2014\end{array}$ & $\begin{array}{l}2000- \\
2013\end{array}$ & $\begin{array}{l}\text { USA (Rhode } \\
\text { Island) }\end{array}$ & No & $\begin{array}{l}\text { Regression based on } \\
\text { DID model } \\
\text { (proximity and } \\
\text { viewshed) }\end{array}$ & 48,554 & $\begin{array}{l}\text { Individual } \\
\text { wind turbine }\end{array}$ \\
\hline GIBBONS 2014 & $\begin{array}{l}2000- \\
2011\end{array}$ & $\begin{array}{l}\text { England and } \\
\text { Wales }\end{array}$ & $\begin{array}{l}\text { Negative: } \\
-5.4 \% \text { to }-5,8 \% \\
\text { for } 0-2 \mathrm{~km}\end{array}$ & $\begin{array}{l}\text { Regression based on } \\
\text { DID model } \\
\text { (visibility from wind } \\
\text { farms) }\end{array}$ & $\begin{array}{l}\text { app. } \\
38,000\end{array}$ & $\begin{array}{l}\text { Wind farms } \\
\text { (mean turbine } \\
\text { has } 11 \text { turbines } \\
\text { with a capacity } \\
\text { of } 18.6 \mathrm{MW} \text { ) }\end{array}$ \\
\hline $\begin{array}{l}\text { DRÖES, KOSTER } \\
2014\end{array}$ & $\begin{array}{l}1985- \\
2011\end{array}$ & Netherlands & $\begin{array}{l}\text { Negative: }-1.4 \% \text { to } \\
-2.3(0-2 \mathrm{~km})\end{array}$ & $\begin{array}{l}\text { Regression based on } \\
\text { DID model } \\
\text { (proximity of wind } \\
\text { turbines) }\end{array}$ & $\begin{array}{l}\text { app. } \\
150,000\end{array}$ & $\begin{array}{l}\text { Individual } \\
\text { wind turbines }\end{array}$ \\
\hline
\end{tabular}

Source: own work.

\section{Hedonic pricing model}

The review of literature presented in the previous section suggests that, over the last years, researchers interested in the problem of the impact of wind farms on nearby housing prices have moved towards more reliable quantitative analysis. Econometric models applied to real estate transactions have, thus, became commonly used methods to estimate property prices and explain the relationship between the variables shaping those prices. Since the use of these models often requires a solid background in econometric modelling, they are used particularly by scholars working in this field (e.g. Bitner 2010; CZAJA, Ligas 2010; SAWIEOW 2010; CellMER, SZCZEPANKOWSKA 2015). Econometric models enable market phenomena to be explained in a broader spectrum and provide a basis for statistical inference. On one hand, they are useful in simulating transaction prices, but on the other hand, they are also important for predicting the response of the prices to external effects (CELLMER, SZCZEPANKOWSKA 2015).

Econometric models used to estimate property values determined by both internal and external factors are commonly referred to as hedonic pricing models (HPM). As stated by SIRMANS et al. (2005), the basic HPM for real estate takes the following form:

$$
\text { Price }=f \text { (Physical Characteristics, Other Factors) }
$$

In this model, physical characteristics represent internal attributes, while other factors stand for external attributes. Following Sirmans et al. (2005), Carter (2011), for instance, defined the general HPM for real estate as the selling price, being a function of both house and neighborhood characteristics. Regardless of the differences in labeling the different categories of variables, the general message is the same: the equation simply says that the housing price is a function of the physical characteristics of a house (e.g. number of bedrooms, usable area, age of building, etc.), whereas other factors correspond to location and environmental/external factors, such as the proximity to a wind turbine or its visibility.

In general, HPMs come down to regression analysis, which makes it possible to determine the change in the property prices caused by an independent variable, while other variables are kept fixed (ceteris paribus condition). In other words, the regression results indicate how much property values change for a small change in each characteristic, keeping all other characteristics constant. In order to avoid problems with the inconsistency of the results for different price ranges, HPMs define the dependent variable as a natural logarithm of price (SIRMANS et al. 2005). Such model specification also exhibits some desirable properties in terms of the interpretation of the estimated coefficients. In particular, the estimated regression coefficients alongside independent variables, which are continuous variables, may be interpreted as a percentage change in the dependent variable (price) caused by a unitary change of the independent variable (WOOLDRIDGE 2003).

Recently, some new methodological approaches to estimating the causal effect of wind farms on property prices have been proposed. Most importantly, most researchers now use advanced econometric methods, which aim to account for other - previously ignored - factors that may be important for the final results (e.g. visibility, anticipation effect). Researchers have thus moved from 
simple hedonic pricing models using regression analysis to more advanced methods, such as spatial fixed effects or difference-in-difference models. The difference-in-difference model has some desirable properties and has been successfully implemented in the above reviewed analyses of HINMAN (2010), GIBBONS (2014), DRÖES and KOSTER (2014). It is, thus, worth discussing this model in more detail and considering the possibility of its application Poland - a country still missing reliable quantitative analysis of the impact of wind farms on nearby property prices.

\section{Difference-in-difference model}

Simple HPMs based on multivariate linear regression are mostly criticised for having problems with heteroscedasticity and spatial autocorrelation (CARTER 2011). They also do not account for the welldocumented anticipation stigma/effect, which leads to biased estimates. To account for this problem, recent studies related to the valuation of the effects of wind farms on housing prices have been extensively using the difference-in-difference (DID) model (HOEN et al. 2009, 2013; HINMAN 2010; LANG et al. 2014; SUNAK, MADLENER 2013).

This model is the recommended tool for determining the causal effect of a certain event or policy. The advantage of this model is that it allows for identifying the causal effect by eliminating the bias of the estimate by double differentiation (WOOLDRIDGE 2003). When applied to wind farms and their effect on housing properties, the model comes down to the comparison of property prices nearby a wind farm (treatment group) with the prices of similar properties where a wind farm does not exist (control group) at two points in time: 1) before the actual building of the wind farm and 2) after it was is constructed. In other words: "DID models typically compare treated units to untreated units, both before and after treatment has occurred" (LANG et al. 2014). The graphical interpretation of a DID model has been presented in Fig. 1.

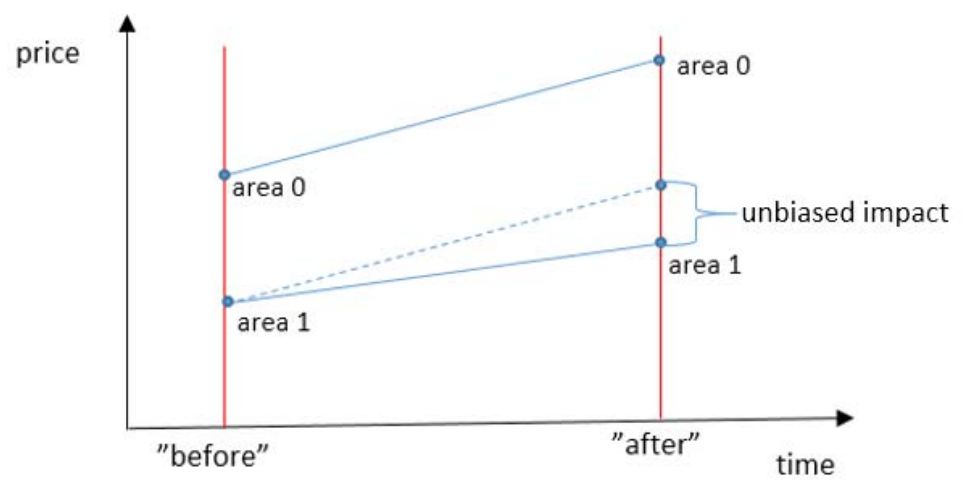

Fig. 1. Difference-in-difference model applied to the analysis of building a wind farm on property prices. Source: own work based on Wooldridge (2003).

In consequence of double differentiation (in time and location), the method allows for eliminating the selection bias which stems from the fact that the location of wind farms may already be unattractive before their construction, meaning that the prices of nearby houses can be lower before the wind farm has even existed. As previous studies show (SIMS et al. 2008; LANG 2014), investors prefer to locate wind farm facilities in places that are distant from strictly residential areas. They are, thus, able to avoid community protests and a prolonged preparatory development process, as well as often acquiring property rights for less attractive (and hence cheaper) locations. Using DID estimation, it is possible to eliminate this selection bias stemming from the unobserved attributes of certain locations, and hence focus on effective external impacts.

Formally, the basic DID model takes the form of:

$$
\text { price }=\alpha_{0}+\alpha_{1} \text { time } 2_{i}+\alpha_{2} \text { areaWF }+\alpha_{3}(\text { time } 2 * \text { areaW } F)+\sum_{4}^{k} \alpha_{k} X_{i}+\varepsilon_{i}
$$

Where the dependant variable is specified as the price of a property; time 2 is a dummy variable equal to 1 for the post-construction phase and 0 for the pre-construction phase, areaWF is a dummy variable equal to 1 for the area within the influence of a wind farm and 0 for the area beyond its influence, time $2 *$ areaWF is the interaction term of the above-mentioned variables. Additionally, independent variables marked as $X_{i}$, which denote property and neighbourhood characteristics (e.g. usable area, age of building, distance from a main road, etc.) are also controlled. Coefficient $\alpha_{3}$ shows 
the effective (unbiased) impact of wind farm facilities, including both price differences within and beyond a pre-defined area of wind farm influence, and the price difference caused by time. In consequence, coefficient $\alpha_{3}$ may be interpreted as follows:

$$
\alpha_{3}=\left(\overline{\text { price }}_{\text {area } 1, \text { after }}-\overline{\text { price }}_{\text {area } 0, \text { after }}\right)-\left(\overline{\text { price }}_{\text {area } 1, \text { before }}-\overline{\text { price }}_{\text {area } 0, \text { before }}\right)
$$

Where the first part of the equation shows the average price difference between the treatment and control group in the post-construction phase, and the latter part reflects differences between the average prices of the treatment and control groups in the pre-construction phase. In consequence, double differentiation allows the unbiased impact of wind turbine location on property prices to be determined.

\section{Conclusion}

This article synthesizes the current state of knowledge with respect to the economic impact of wind farms on the prices of nearby houses. The analysis of scientific literature on the topic concerning Poland reveals that, so far, it has been rather neglected. Due to the rapid development of the wind energy sector that has been observed over the last 5-6 years, there is, however, a great need to fill this terra incognita. International scientific literature, on the other hand, is well-developed, but focuses mostly on Western European countries (UK, Netherlands, Germany) and the USA, which are characterized by a highly developed wind farm infrastructure. These countries face different legal, social and economic backgrounds in the context of wind energy than Poland. Their results cannot thus be simply transposed to Polish circumstances.

The review of literature shows that most of international analyses of the effects of wind farms on property prices are based on quantitative research adapting hedonic pricing models. Future studies related to Poland should, therefore, focus on quantitative analysis to improve the reliability of the results, mainly by incorporating the proposed methodologies (e.g. difference-in-difference estimation), along with adjusting to conditions specific for Poland.

\section{References:}

BITNER A., 2010, On the Usefulness of Statistical Methods in Real Estate Valuation, PAN, Infrastructure and Ecology of Rural Areas, No.: 12/2010.

CARTER, J. (2011) The Effect of Wind Farms on Residential Property Values in Lee County, Thesis, Illinois State University, Spring 2011, pp. 1-35.

CELLMER R., SzCZEPANKOWSKA K., 2015, Use of Statistical Models for Simulating Transactions on the Real Estate Market, Real Estate Management and Valuation, No. 23(2),pp. 99-108.

CZAJA J., LIGAS M., 2010, Zaawansowane metody analizy statystycznej rynku nieruchomości (Advanced statistical analysis for real etstate market research), Studia i Materiały Towarzystwa Naukowego Nieruchomości, No. 18(1), pp. 7-20.

Directive 2009/28/EC of the European Parliament and of The Council of 23 April 2009 on the promotion of the use of energy from renewable sources and amending and subsequently repealing Directives 2001/77/EC and 2003/30/EC.

DRÖES M.J., KOSTER H.R.A., 2014, Renewable Energy and Negative Externalities: the Effect of Wind Turbines on House Prices, Tinbergen Institute Discussion Paper.

Energy Resources in Poland, Polish Geological Institute, retrieved from: www.geoportal.pgi.gov.pl.

Energy Statistics in 2012 and 2013, Statistical Information and Elaborations, Central Statistical Office for Poland, Warsaw 2014, retrieved from: www.stat.gov.pl.

GIBbONS S., 2014, Gone With the Wind: Valuing the Visual Impacts of Wind Turbines Through House Prices, London School of Economics and Political Sciences \& Spatial Economics Research Centre, SERC Discussion Paper 159 (April 2014).

Global Wind Report, Annual Market Update 2014, retrieved from: www.gwec.net.

Heintzelman M.D., Tuttle C., 2011, Values in the Wind: A Hedonic Analysis of Wind Power Facilities. Land Economics, Forthcoming. Available at SSRN: http:/ / ssrn.com/abstract=1803601

HinMAN J.L., 2010, Wind Farm Proximity and property values: A pooled Hedonic Regression Analysis of Property Values in Central Illinois, Thesis, Illinois State University, May 2010, pp. 1-143. 
Hoen B., Wiser R., Cappers P., Thayer M.A, Sethi G., 2009, The Impact of Wind Power Projects on Residential Property Values in the United States: A Multi-Site Hedonic Analysis, Lawrence Berkeley National Laboratory (LBNL), LBNL Report LBNL-2829E, Berkeley, United States, pp. 1-146.

Hoen B., Brown J.P., JACKSON T., Wiser R., ThAyer M.A., CAPPERS P., 2013, A Spatial Hedonic Analysis of Wind Energy Facilities on Surrounding Property Values in the United States, Lawrence Berkeley National Laboratory (LBNL), LBNL Report LBNL-6362E, Berkeley, United States, pp. 1-51.

KHATRI M., 2004, RICS Wind Farm Research: Impact of Wind Farms on the Value of Residential Property and Agricultural Land. Prepared for Royal Institute of Chartered Surveyors, London, UK.

KOMORNICKI T., ROSIK P., ŚWIĄTEK D., WIŚNIEWSKI R., MILEWSKI P., 2011, Badania społeczno-ekonomiczne wykorzystania energetyki wiatrowej (Socio-economic research regarding the use of wind Energy), moduł B1 (Module B1), PAN IGiPZ.

Krajowy plan działania w zakresie energii ze źródeł odnawialnych, (National Renewable Energy Action Plan), Ministry of Economy, Warsaw, 2010.

LANG C., Opaluch J.J., SFinarolaKis G., 2014, The Windy City: Property Value Impacts of Wind Turbines in an Urban Setting. Energy Economics, no. 44, pp. 413-421.

Ligus M., 2009, Efektywność inwestycji w odnawialne źródła energii - analiza kosztów $i$ korzyści, Wydawnictwo (The Effectiveness of Investments in Renewable Energy Sources - Cost-benefit Analysis), CeDeWu.

Lokalizacja i budowa lądowych farm wiatrowych, Informacja o wynikach kontroli (Location and Construction of Wind Farms - Audit Findings), 2015, Najwyższa Izba Kontroli (Supreme Audit Office in Poland), retrieved from: www.nik.gov.pl.

NieuWENHUIZEN E., KÖHL M., 2015, Differences in Noise Regulations for Wind Turbines in Four European Countries, Proceedings: Euronoise 2015 paper, 31 May - 3 June, pp. 333-338.

Polityka Energetyczna Polski do 2030 (Energy Policy of Poland until 2030), Appendix to Resolution No. 202/2009 of the Council of Ministers , Ministry of Economy, 2009, Warsaw.

SAWIŁOW E., 2010, Problematyka określania wartości nieruchomości metoda analizy statystycznej rynku (The Problems of Qualifying the Value of Real Estate with the Method of the Statistical Analysis of the Market), Studia i Materiały Towarzystwa Naukowego Nieruchomości (Journal of the Polish Real Estate Scientific Society), No. 8(1),pp. 21-32.

Sims S., Dent P., OsKRochi G. R., 2008, Modelling the Impact of Wind Farms on House Prices in the UK, International Journal of Strategic Property Management, no. 12(4), pp. 251-269.

SIRMANS S., MACPHERSON D., ZIETZ E., 2005, The Composition of Hedonic Pricing Models. Journal of Real Estate Literature, No. 13(1), pp. 1-44.

SMITH L., 2015, Planning for Onshore Wind, House of Commons, Briefing paper, No: 04370, pp. 1-23.

SunAK Y., MADLENER R., 2014, Local Impacts of Wind Farms on Property Values: A Spatial Difference-inDifferences Analysis, Institute for Future Energy Consumer Needs and Behavior, RWTH Aachen University, FCN Working Paper, No. 1, pp. 1-29.

Rozporządzenie Ministra Środowiska z dnia 1 października 2012 r. zmieniające rozporządzenie $w$ sprawie dopuszczalnych poziomów hałasu w środowisku, Dziennik Ustaw z 2012 r., nr 0, pozycja 1109 (Regulation of the Minister of the Environment changing the regulation on permissible sound levels in the environment of 1 October 2012, Journal of Laws of 2012, No. 0, item 1109).

WAlKer C., BAXTer J., MASON S., LuginAaH I., OuelletTe D., 2014, Wind energy development and perceived real estate values in Ontario, Canada, AIMS Energy, No. 2(4), pp. 424-442.

Wooldridge J.M., 2003, Pooling Cross Section Across Time: Simple Panel Data Methods, in: Introductory Econometrics: A Modern Approach, Mason, OH: Thomson/South-Western. 